\title{
Un día en la vida de un residente de pediatría
}

\section{A day in the life of a pediatric resident}

\author{
Dra. Rosa A Cano De La Vega* \\ * Médico Residente de tercer año de Pediatría del Instituto Nacional de Pediatría (INP). México. \\ Citar como: Cano De La Vega RA. Un día en la vida de un residente de pediatría. Alergia \\ Asma Inmunol Pediatr. 2021; 30 (2): 35-36. https://dx.doi.org/10.35366/101639
}

Un lunes, me levanto a las 5:20 de la mañana para bañarme y arreglarme, tengo la fortuna de vivir frente al hospital y en cinco minutos estoy en el piso de infectología como R3. Antes de las seis llego al control de infecto 1 y saludo a mis R1 que tienen una hora revisando a sus respectivos niños y haciendo las indicaciones del día que empieza. Entro a ver a mi paciente más grave en el aislado, reviso su hoja de terapia continua, los parámetros del ventilador con que lo recibo, lo ausculto y exploro, intercambio un par de palabras con la mamá que, por supuesto, no quiere despegarse ni un segundo: «ícómo pasó la noche?»; lo dejo y reviso uno a uno mis expedientes, leo las notas de los R1 del día anterior, les subrayo o escribo anotaciones en las mismas para que más adelante las puedan corregir, me pasan las indicaciones listas para que yo revise cada medicamento o solución administrada, debo estar muy pendiente de las dosis por kg de peso, de los planes del día anterior para que no haya errores, las firmo.

A las siete inicia la entrega con los residentes de subespecialidad y el adscrito de los lunes que cambia diariamente, el R3 que estuvo de guardia nos cuenta frente a la puerta de cada paciente cómo pasaron la tarde-noche del día anterior, las eventualidades, fiebres; es el momento en que como R1 solía temblar porque es una hora en que aprovechan los subs para preguntarte: «ipara qué sirve la colistina?», «zqqué microorganismo le quieres cubrir con este antibiótico específico?», siguiente paciente, «¿̇criterios de alto riesgo de fiebre y neutropenia?», siguiente paciente... Afortunadamente, aún tengo la libreta de hace dos años y sólo me queda repasar lo aprendido. Terminando la entrega dejo tarea a los R1, «fulanita, tu paciente tiene una infec- ción por Clostridioides, mañana nos vas a platicar cómo la tratas porque hoy no contestaste», y es una oportunidad más para volverlo a repasar.

A las ocho corremos a desayunar, de dos en dos y no más de 15 minutos, pues ya estoy colocando los pendientes en un pequeño pizarrón frente al control de enfermería: paciente de la cama 418 presentar para ultrasonido abdominal, 433 interconsulta con neurología, 445 PCR y procalcitonina... Ellos adelantan lo más posible y los veo subir y bajar, me preguntan todo el tiempo «iRosy puedes revisar a este niño, me quedó duda de su mucositis?», «之ंRosy qué le digo al sub de neuro?», «i̇En qué tubo va una PCR?». Pareciera que pasan horas porque hacemos mil cosas, pero no son tantas, a las 10:30 llega la adscrita a cargo a pasar visita, acomodamos todos los expedientes a su izquierda y las indicaciones a su derecha, se acompaña de un R4 y un R5 de infectología, mis R1 comienzan a presentar niño por niño, nombre y edad, diagnóstico y qué ha pasado con él, «perenganito iba a irse de alta, pero anoche tuvo fiebre y hoy por la mañana le tomamos laboratorios, estos son los resultados...»; comentamos entre todos los posibles diagnósticos, es un momento más para que nos hagan preguntas del paciente, de su patología, de cómo hay que tratarla, finalmente establecemos un nuevo plan y siguiente paciente.

Conforme avanza el pase voy anotando nuevos pendientes en el pizarrón y sólo veo la cara de estrés de todos porque parece que el día no alcanzará, puede pasar una o dos horas y finalmente acabamos, me toca dar informes a los padres junto con la adscrita, vamos cama por cama con cada uno, explicando lo más sencillo posible el plan 
que acabamos de establecer y respondiendo sus dudas. A las 12:30 me toca bajar a urgencias a dar camas, ya sé qué pacientes se irán y cuántas camas tendré disponibles, por lo que bajo a que nos presenten a los niños que pueden subir a continuar tratamiento con nosotros y elegimos quiénes serán, siempre hay más de los que caben, pero intentamos ser lo más justas posibles.

A la una vuelvo a subir porque nos darán clase por zoom, nos conectamos desde donde cada uno puede y el R4 nos presenta un tema, «varicela», la adscrita nos pregunta a todos, de abajo hacia arriba en jerarquía, aumentando su nivel de dificultad, y veo otra vez las caritas de susto de los residentes más pequeños, más para leer por la tarde sin duda. Terminando la clase pregunto por los avances en pendientes: «¿Qué pasó con el ultrasonido que pedí?», «¿QQué comentó el radiólogo de él?»... Me dan las altas impresas para que las revise y las firme, le entrego las recetas a los papás y les doy indicaciones y datos de alarma para casa.

A las tres de la tarde empieza a urgir hacer el censo, se sientan todos a actualizarlo, colocar los resultados de los nuevos laboratorios y actualizar los diagnósticos, cambiar los días de antibiótico para nunca perder el control, borrar a los que se fueron de alta, colocar a los nuevos que ingresarán, poco a poco volvemos a bajar corriendo a comer, esta vez tenemos escasos 10 minutos porque falta mucho por hacer. A las cuatro de la tarde se recibe la guardia y el censo debe estar impecable. Llega el R3 que se quedará con mis niños, quizá 15 minutos antes, y yo le entrego los pendientes más importantes, entramos a ver a mi niño grave, le explico los cambios que hicimos con el ventilador acorde a la gasometría y por qué tomamos la decisión de hacer punción lumbar al día siguiente, se lo encargo especialmente. Mientras recibe el piso, nuevamente cama por cama de boca de cada uno de los R1 y R2 que estaban cuidándolos por la mañana yo no puedo irme, hay un niño del otro lado del piso que «se puso feo», avisaron que tiene fiebre y mucha taquicardia, voy a revisarlo mientras mi compañero sigue ocupado, la entrega puede tardar una hora o quizá dos, así que el niño no puede esperar tanto, decido pasarle una carga de solución porque su tensión arterial (TA) está disminuyendo, le colocamos un monitor, la enfermera y un R1 preocupado se quedan conmigo, lo revisamos y esperamos... finalmente entregaron todo el piso y veo a mi compañero R3 acercarse «iqué pasó?», lo pongo al tanto, platicamos otra vez opciones, decidimos tomar muestras de laboratorio y comentarlo con alguien de infectología, lo dejo.

Finalmente llego a mi casa a las seis de la tarde, por alguna razón estoy muerta, juraba que de R3 me cansaría menos, pero siento que caminé todo el día, me duermo una hora y me levanto a cenar, pongo una serie, algo cortito para ver mientras ceno porque ya vi la lista de cosas anotadas en una hojita doblada en donde anoté lo que tengo que repasar, y estudio lo que le preguntaré a mi R1 mañana, la técnica de punción lumbar (porque haré una muy temprano al llegar), y gasometría (cómo me cuesta entenderlas desde siempre), pero ahorita mi niño favorito depende de mis decisiones con sus gasometrías. Se levanta mi roomie, estuvo de guardia ayer en urgencias, así que durmió mucho más por la tarde, platicamos un rato, una o dos lágrimas y 20 quejas de las dos, ¿̇por qué todo parece tan difícil? Hablamos otra vez del hospital, de mis niños, mis pacientes, sus dudas y mis inseguridades, nos quejamos de los residentes nuevos, de los viejos y finalmente nos reímos mucho. ¿Qué estamos haciendo?, quién sabe, pero de alguna forma, entre tanto cansancio parece que nos gusta vivir con la adrenalina todos los días, un poco a prisa y un poco con la cabeza llena todo el tiempo.

Un mensaje, es la coordinadora de los subs de infecto: mis respetos para ustedes, lo han hecho increíble esta semana con los pacientes. Listo, lo vale todo. 